\title{
Menelusuri Daya Tahan Wanita Islam Generasi Awal Bagi Mencapai Keunggulan Melalui Analisis Wacana Hadis Nabawi
}

\author{
Ariza Abdullah, Mohd Azidan Abdul Jabar*, Nik Farhan Mustapha, Pabiyah Toklubok@Hajimaming \\ Jabatan Bahasa Moden, Fakulti Bahasa Moden \& Komunikasi, Universiti Putra Malaysia 43400 Serdang, Selangor, Malaysia \\ *Corresponding author: azid@upm.edu.my
}

\begin{abstract}
Women are the main driving force of society along side men. High personality of women will bring into the world strong generation and community in facing challenges of life. If they are weak, the community also will become strengthless. Muslims, regardless being majorities in Moslem countries or minorities in non Moslem countries should revive excellency as early generations of Islam that bring forth advanced world civilization for several centuries. The stories of the early generations had been written by many authors such as Mohammad Rashid Rida's writing about the wives of the Prophet, as well as contained in history books known as "sirah", autobiographies as well as other forms of writings, translations of thousands of titles in the subject but not studied analytically. Thus analyzing the social processes that apply at that time through the content of Prophetic hadith and discourse analysis texts as proposed by social language analysts, prevail to expose the excellency and sustainability of women implied in the events as had been narrated by themselves and others. Methodology of this study is based on analysis of the content of hadith and Fairclough (2003, 1992, 1989)'s concept of discourse analysis through the dimension of intertextuality. Several prophetic Hadith are selected, analyzed and being related to social practice to formulate the principles that should serve as a model to modern women especially by Moslim women. This is because the development of human capital especially female identity is the backbone of the nation's development.
\end{abstract}

Keyword: Female identity; first generation; Prophet's wives; analysis of discourse practice dimension; intertextuality; social practice

\begin{abstract}
Abstrak
Wanita merupakan tenaga penggerak utama masyarakat di sisi kaum lelaki. Jati diri wanita amat tinggi, beliau mampu melahirkan anak generasi kesinambungan mereka kuat menghadapi segala dugaan. Sekiranya mereka lemah, maka lemah dan mundurlah masyarakat. Umat Islam,tidak kira sebagai kaum majoriti atau minoriti di mana sahaja mereka berada sepatutnya bangkit menggungguli dalam banyak perkara sebagaimana generasi awal Islam mereka telah melahirkan tamadun yang maju sehingga berabad. Penulisan mengenai generasi awal ini banyak disebut dalam buku-buku sirah dan sejarah seperti tulisan Mohammad Rashid Ridha mengenai isteri Nabi berbentuk autobiografi dan terjemahan, melebihi ribuan judul berbentuk kisah naratif. Kajian ini menelusuri semula proses simulasi sosial yang berlaku pada zaman itu, menerusi analisis kandungan dan analisis wacana teks hadis nabawi sebagaimana yang dicadangkan oleh para penganalisis sosial bahasa,. Maklumat tersirat di dalam teks hadis di sebalik peristiwa yang berlaku ke atas mereka sendiri dan para sahabat sezaman berjaya menggarap kecemerlangan dan daya tahan wanita tersebut.. Metodologi kajian ini berdasarkan analisis kandungan hadis dan analisis wacana dari dimensi intertekstualiti amalan wacana Fairclough $(2003,1992$, 1989).Teks hadis nabawi yang terpilih dianalisis dan dikaitkan dengan praktis sosial di samping dihubungjalin untuk merumuskan asas yang patut diteladani oleh wanita kini, terutamanya para muslimah.Ini kerana pembangunan modal insan dan pembinaan jatidiri wanita menjadi tonggak yang penting dalam pembangunan negara.
\end{abstract}

Kata kunci: Jati diri wanita; generasi awal; isteri Nabi; dimensi amalan wacana; intertekstualiti; proses sosial

(C) 2017 Penerbit UTM Press. All rights reserved

\subsection{PENDAHULUAN}

Generasi awal Muslim adalah contoh terbaik kualiti individu yang dihasilkan daripada pendidikan al-Quran secara langsung. Pendidikan ini telah tersebar di segenap pelusuk dunia, termasuk mereka yang berada majoriti di negara-negara Islam atau minoriti di beberapa Negara-Negara bukan Islam seperti Amerika, China dan Asia. Umat Islam di Rantau Pasifik, bukan majoriti, kerana hanya beberapa buah Negara Islam sahaja seperti Malaysia, Indonesia dan Brunei.Tidak kira di mana sahaja mereka berada mereka perlu bersaing dan menunjukkan contoh yang terbaik, kerana mereka telah dibekalkan dengan sumber Ilahi, sumber ini terbukti melalui sejarah ketamadunan Islam kejayaannya. Namun begitu umat Islam masih tidak berjaya bangkit membina ketamadunan moden, kerana kelemahan sumber manusia yang gagal untuk mencontohi Rasulullah SAW. Generasi awal Islam diiktiraf sendiri dalam al-Quran (Ali Imran:110) sebagai sebaik-baik ummah (khaira ummah):

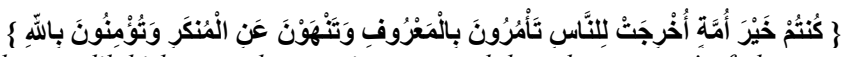

Ertinya: Kamu adalah umat yang terbaik yang dilahirkan untuk manusia, menyuruh kepada yang ma'ruf, dan mencegah dari yang mungkar, dan beriman kepada Allah. 
Mereka perlu mempunyai kualiti keperibadian yang tinggi dan berpemikiran jelas untuk mencapai pengiktirafan itu supaya dapat menjalankan perkara-perkara kebaikan dan menjauhkan diri daripada keburukan (ta'muruna bil ma'ruf wa tanhauna 'anil munkar). Salah satu cara untuk membangunkan umat Islam ialah melalui kaum wanita, mereka merupakan ibu kepada anak-anak generasi baru dan tonggak kepada masyarakat. Tugas ini digalas secara langsung kerana tuhan telah membekalkan mereka dengan fungsi-fungsi fisiologi, emosi serta fitrah yang sesuai. Untuk menjalankan tanggungjawab ini, mereka perlu mengikut acuan sebenar Islam dengan mematuhi jati diri Muslim, serta tidak terpengaruh dengan identiti yang dicorakkan oleh Barat.

\subsection{KAJIAN LITERATUR}

\section{Kajian Sosial}

Kajian dan penulisan bagaimana Nabi mentarbiah para wanita terdapat dalam kajian al-Moumani (2013),al-Najjar (2009), al-Budur (2010), dan al-Majid (2010). Al-Moumani yang mengkaji bagaimana pergaulan Nabi Muhammad SAW bersama dengan isteri baginda Aisyah, kehalusan budi Rasulullah SAW dalam berdakwah, amat meraikan minat kaum wanita. Al-Majid meneliti beberapa sudut tarbiah daripada sirah Ummahatul Mu'minin, dan Al-Qannuji al-Bukhari (1981) telah mengumpulkan ayat-ayat dalam al-Quran dan Hadis Nabawi yang menyebut tentang wanita, sebanyak 193 ayat al-Quran dan 479 hadis menghuraikan penerangan pendek. Ayat al-Quran, hadis dan sirah boleh dijadikan panduan kepada para wanita secara amnya tidak mengaitkan dengan bahasa untuk meneliti keperibadian mereka secara khusus.

Terdapat juga kajian yang mengulas pandangan ulama seperti Muhammad al-Ghazali, Hasan al-Banna dan al-Maududi dalam mengambilkan pegangan dan tarbiah yang terbaik kepada wanita lebih-lebih lagi di zaman globailsasi yang berdepan dengan berbagai keadaan dan pertembungan budaya serta anutan yang bercelaru. Namun kesemua ulama sepakat mengatakan kepentingan ilmu kepada wanita, terutamanya ilmu yang berasaskan al-Quran di samping ilmu lain supaya mereka dapat menjalankan fungsi seperti yang dikehendaki penciptanya kepadanya sepatutnya disemai dengan akhlak dan adab yang mulia.

Terdapat banyak penulisan berbentuk autobiografi perihal para isteri Nabi secara am, seperti kitab al-Sha'rawi (2001), perjalanan para wanita generasi pertama turut ditulis oleh Muhammad Ibrahim Salim (1990) bagi tujuan memberi contoh keperibadian para wanita unggul melalui kisah hidup mereka. Selain itu terdapat fokus memperihalkan peranan utama Saiyidatina Aisyah RA yang banyak menyumbang dalam tradisi ilmu antaranya ensiklopedia karya Abdul Mun'im al-Hanafi (2003), siri terbaru ensiklopedia dalam talian dilancarkan pada tahun 2013 oleh al-dorar.net, ia merujuk sebanyak 570 karya yang menyebut tentang Ummul Mu'minin Aisyah RA sama ada dari pihak ahli Sunnah ataupun Syiah, menekankan peranan diberi kepada beliau serta menolak segala tohmahan ke atas beliau. Selain dari itu peranan ahli keluarga Nabi yang lain turut dibahaskan dalam banyak penulisan. Namun kajian-kajian sosial yang signifikan ini masih belum mencukupi tanpa menggabungkannya dengan kajian bahasa yang turut menyumbang dalam memberi penyelesaian terhadap permasalahan sosial. Oleh itu, kajian yang menggabungkan antara sosial dan bahasa perlu diadakan lebih-lebih lagi menyelusuri detikdetik kehidupan generasi pertama melalui periwayatan mereka untuk mengambil kekuatan dalaman sebagai sumber motivasi ke arah kebangkitan wanita generasi ini.

\section{Kajian Wacana Hadis}

Bahasa sebagai wahana ilmu (Bullock, 1976; Marland, 1977; Greenwood, 1985; Halliday, 1985; Awang Sariyan, 2007) meliputi pelbagai bidang kehidupan. Ia bukan sahaja suatu sistem komunikasi manusia yang terdiri daripada bunyi atau bentuk tertentu bahkan ia juga sebahagian daripada sistem sosial dan budaya sesuatu masyarakat. Ia menjadi semakin penting dalam era teknologi maklumat dan globalisasi ini, kerana ia menjadi medium untuk mengawal dan mencorakkan masyarakat melalui kefahaman serta ideologi yang dibawa di samping nilai-nilai yang ingin diterapkan (Fairclough, 1989). Bahasajuga berfungsi mendominasi perhubungan melalui penggunaan bahasa dalam proses sosial dan budaya yang lebih luas (Fairclough, 1992). Melalui analisis wacana, pelbagai kefahaman, ideologi, norma dan nilai-nilai yang tumpat akan dapat disingkap dan dihuraikan.

Hadis sebagai sumber wacana kedua umat Islam mendapat perhatian pelbagai pihak dalam setiap era, sejak dari zaman para sahabat baginda SAW. Bermula daripada usaha pengumpulan hadis, penghuraiannya, pengistinbatan hukum serta kajian tentang bahasa (nahu) dan keindahan bahasa (balaghah) telah melahirkan banyak karya agung. Walaubagaimanapun, analisis genre agama, terutamanya kajian tentang perkaitan antara bahasa dan sistem sosial di era ini, masih tidak dimanfaatkan sepenuhnya untuk diteliti, bagaimana proses sosial yang dibuktikan melalui aspek tekstual dan amalan wacana dilangsungkan di dalam bahasa.

Antara analisis wacana hadis secara kritis dikemuka oleh Mohd Akil Muhammad Ali, Mazlan Ibrahim, Dwi Sukmanilla Sayska (2011) daripada UKM membuat artikel bertajuk "Hadith Anti Wanita berkenaan Kehidupan Rumahtangga: Kritikan terhadap Feminis Liberal." Hasil dapatan daripada analisis ini mendapati kesalahfahaman para feminis liberal terhadap hadis Nabi berpunca daripada dasar pandangan mereka terhadap pemahaman hadis yang berteraskan ideologi kesetaraan gender dan persamaan mutlak antara lelaki dan wanita serta tidak mengaitkannya dengan semua nas yang berhubungan dengan tujuan hadis-hadis tersebut.

Begitu juga kajian tentang aspek kepimpinan oleh Munif Zariruddin Fikri (2008) yang bertajuk "Bahasa Kepimpinan Rasulullah SAW: Analisis wacana khutbah Ghazawat al-Rasul membuktikan kebijaksanaan Rasulullah SAW sebagai seorang pemimpin dan kepentingan bahasa dalam kepimpinan lebih-lebih lagi dalam khutbah peperangan untuk membangkitkan semangat para pejuang Islam.Dengan menggunakan metodologi analisis wacana kritis tiga dimensi Fairclough (1995) beliau telah membahaskan strategi bahasa kepimpinan Rasulullah SAW menggunakan beberapa khutbah baginda. Analisis ini membuka dimensi baru dalam analisis wacana genre agama dengan mempertalikan hubungan manusia dengan tuhan berlandaskan pendekatan al-Quran melalui teori dan model Barat. Melanjutkan lagi usaha ini, kajian terhadap isu-isu sosial perlu dikaitkan dengan teras al-Quran dan hadis nabawi sebagai jalan penyelesaian dan perlu dikaji secara mendalam termasuk dari aspek penggunaan bahasa, struktur wacana serta penghasilannya. Kertas kerja ini satu analisis daripada bahasa hadis untuk membuktikan proses sosial yang terdapat di dalamnya melangkaui sempadan tempat dan masa serta teramat relevan untuk digunapakai di zaman serba canggih dan moden.

Justeru itu, kajian bahasa hadis ini ialah untuk menjawab persoalan berikut: 
1. Bagaimanakah amalan wacana melalui penghasilannya dapat memberi impak kepada keunggulan wanita terdahulu?

2. Apakah asas yang dipupuk kepada generasi wanita terdahulu yang dikesan melalui teks hadis yang perlu dicontohi oleh wanita di zaman ini?

\subsection{REKABENTUK KAJIAN}

Untuk mendapatkan analisis yang teratur dan jelas, kajian ini mengambil sandaran kerangka teori bahasa analisis wacana kritis (AWK) yang menghubungkaitkan antara bahasa dan kehidupan sosial yang dicadangkan oleh Fairclough (1989, 1992, 1995, 2003) iaitu Model Konsepsi Tiga Dimensi Wacana yang menganalisis teks dari tiga dimensi iaitu pertama dimensi tekstual, kedua, dimensi amalan wacana dan ketiga, dimensi praktis sosial yang menjadi pegangan pewacana ...dan melatari masyarakat (Rajah 1). Di dalam artikel yang terhad ini hanya aspek kedua iaitu aspek amalan wacana dari sudut intertekstual sahaja yang akan diberi tumpuan untuk dikaitkan dengan praktis sosial.

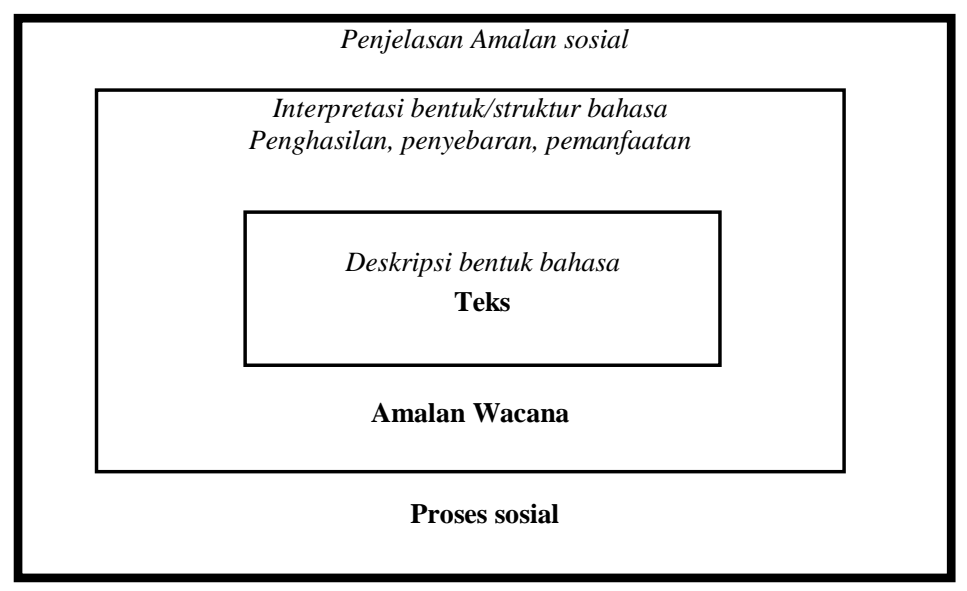

Rajah 1 Model konsepsi 3 dimensi wacana Fairclough (1992)

\section{Analisis Amalan Wacana}

Amalan wacana merupakan dimensi yang menghubungkan antara teks dan proses sosial melalui interpretasi struktur bahasa, penghasilan, penyebaran dan pemanfaatan. Fairclough (1992) telah memasukkan analisis intertekstualiti sebagai satu daripada proses utama penghasilan sesebuah teks.

Analisis intertekstualiti merupakan analisis ciri-ciri kepelbagaian teks yang dimanifestasikan di dalam wacana. Berdasarkan prinsip intertekstualiti, setiap teks yang terhasil adalah gabungan dan transformasi teks silam, iaitu mempunyai unsur, pengaruh dan masukan teks lain. Malah pengaruh unsur sosial, politik, ekonomi dan budaya turut memainkan peranan dalam pembinaan teks. Oleh itu analisis intertekstual bertujuan mengenalpasti teks yang disisipkan dan bagaimana proses penyisipannya. Pengenalpastian unsur intertekstualiti yang dimanfaatkan oleh pewacana akan membantu proses pemahaman hubungan dialektikal antara amalan wacana dengan proses sosial (Idris, 2006)

Di dalam penghasilan teks, intertekstualiti terjadi secara eksplisit dan implisit. Perbincangan di sini hanya akan menumpu kepada intertekstualiti eksplisit di mana masukan teks lain diperlihatkan secara jelas melalui konvensyen tertentu pada aras permukaan teks. Konvensyen itu boleh sama ada secara pernyataan sumber atau tanda-tanda permukaan lain dinamakan penegasan ketara (Idris Aman, 2006) Dua sumber utama iaitu firman Allah SWT di dalam al-Quran serta sabda Nabi Muhammad SAW merupakan interteks berbentuk penegasan ketara yang dikesan dalam analisis ini.

Dimensi amalan wacana di sini dilihat sebagai pengantara antara struktur sosial (dalam masyarakat) dan peristiwa sosial (gaya pengungkapan perawi yang dihasilkan melalui lisan pada mulanya dan kemudian disebar dan dimanfaatkan melalui tulisan) melalui teks hadis nabawi. Fairclough (1992) menekankan praktis sosial ini menghubungkan wacana dengan unsur sosial yang bukan wacana. Wacana seterusnya menjadi representasi yang menjadi sebahagian daripada proses sosial. Praktis sosial iaitu praktis Islami yang menjadi pegangan wanita di dalam hadis inilah yang menjadi sumber kekuatan para wanita generasi awal yang direpresentasikan oleh wacana hadis. Tiga hadis yang paling menonjol membuktikan praktis ini telah dianalisis. Hadis-hadis ini diambil dari kitab Sahih Bukhari yang mana diakui menduduki tempat teratas dalam senarai kitab Sahih (al-Salih, 2000) untuk menjamin kebolehpercayaan natijahnya.

\subsection{ANALISIS DATA}

Tiga buah teks utama yang dikesan mempunyai impak yang besar kepada wanita dalam menulusuri kehidupan telah dipilih untuk analisis intertekstual dalam penghasilan wacana. Tiga hadis tersebut ialah hadis takhyir, hadis Fatimah RA dan hadis Ummu Ismail. Interteks yang dipetik daripada teks riwayat dianalisis kandungan dan kaitannya dengan para wanita tersebut. Prinsip intertekstualiti digunakan secara eksplisit di dalam riwayat hadis oleh para sahabat. Metawacana atau cara pewacana membezakan aras yang berlainan di dalam teks sendiri dan menganggap aras berlainan itu sebagai milikan teks lain dilakukan secara penegasan ketara melalui kata-kata seperti menyebut "sabda 
Nabi S.A.W"atau "Allah S.W.T berfirman" atau menyebut sumber asalnya daripada al-Quran. Kedua-dua sumber ini mendominasi riwayat sahabat yang menyampaikan ajaran Nabi dengan amanah.

\section{Hadis Takhyir}

Hadis takhyir bermaksud memberi pilihan. Di dalam hadis ini para isteri Nabi S.A.W diberi peluang untuk memilih kesenangan dunia atau mahu hidup bersama Rasulullah S.A.W dalam perjuangan baginda. Hadis ini berada dalam Sahih Bukhari, kitab Tafsir: no 308 dan 309 diriwayatkan oleh Aishah kepada Abu Salamah bin Abdul Rahman melalui dua jalur iaitu melalui Abu Yunus dan al-Laith dan kedua melalui Al-Zuhri, Shuaib dan Abu al-Yaman. Kedua-dua teks hampir sama dengan hadis 309 bersama sedikit pertambahan di akhir riwayat.

Terjemahan teks hadis 309:

Berkata al-Laith bahawa Yunus memberitahuku daripada Ibn Shihab yang berkata Abu Salamah bin Abdul Rahman mengkhabarkan bahawa Aisyah isteri Nabi SAW berkata: Ketika Rasulullah S.A.W disuruh untuk memberikan pilihan kepada isteri-isterinya, baginda mulai dengan aku. Baginda bersabda: "Aku akan menyampaikan sesuatu kepadamu dan aku harap kamu tidak terburu-buru mengambil suatu keputusan sebelum kamu pertimbangkan dengan kedua orang tuamu”. Kata Aisyah R.A aku sudah tahu bahawa kedua orang tuaku sama sekali tidak akan menyuruhku berpisah dengan baginda. Kemudian baginda bersabda: Sesungguhnya Allah Yang Maha Tinggi lagi Maha Mulia berfirman: Yang bermaksud: \{Wahai Nabi, katakanlah kepada isteri-isterimu: Jika kamu sekalian inginkan kehidupan dunia dan segala perhiasannya, maka marilah akan kuberikan kepadamu kesenangan dan aku ceraikan kamu dengan cara yang baik dan jika kamu sekalian inginkan keredaan Allah dan RasulNya serta kesenangan di negeri Akhirat, maka sesungguhnya Allah menyediakan bagi siapa yang berbuat baik di antara kamu pahala yang besar.\} Aku berkata: Jadi tentang soal inikah aku disuruh untuk meminta pertimbangan dari dua orang tuaku? Sesungguhnya aku menghendaki Allah dan RasulNya serta kesenangan di negeri Akhirat. [Aisyah berkata: Kemudian isteri-isteri Rasulullah S.A.W yang lain juga mengikuti apa yang aku lakukan itu.

Kajian interteks dalam hadis riwayat Aisyah ini mengandungi dua unsur intertekstualiti iaitu daripada al-Quran dan sabda Nabi Muhammad S.A.W iaitu:

1. Daripada sabda Nabi S.A.W

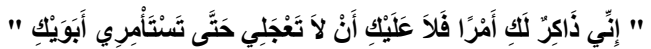

Baginda bersabda: "Aku akan menyampaikan sesuatu kepadamu dan aku harap kamu tidak terburu-buru mengambil suatu keputusan sebelum kamu pertimbangkan dengan kedua orang tuamu."

2. Daripada al-Quran, surah al-Ahzab ayat 28-29

Ayat penuhnya ialah:

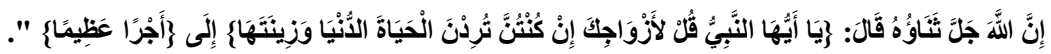

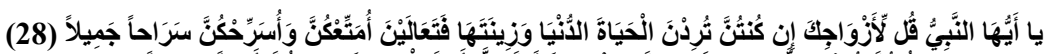

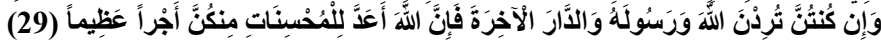

Terjemahan ayat:

"Wahai Nabi, katakanlah kepada isteri-isterimu: "Sekiranya kamu semua mahukan kehidupan dunia (yang mewah) dan perhiasannya (yang indah), maka marilah supaya aku berikan kepada kaти pemberian mut'ah (sagu hati), dan aku lepaskan kamu dengan cara yang sebaik-baiknya.Dan sekiranya kamu semua mahukan (keredaan) Allah dan RasulNya serta (nikmat kemewahan) di negeri akhirat maka sesungguhnya Allah menyediakan bagi orang-orang yang berbuat baik di antara kamu: pahala yang besar."

Interteks berlapis iaitu firman Allah di dalam sabda Nabi S.A.W menunjukkan penyampaian wahyu daripada Allah S.W.T melalui perantaraan Nabi Muhammad S.A.W, lalu disampaikan kepada sasarannya iaitu umat Islam dan khasnya di sini kepada para isteri Nabi Muhammad SAW. Penyampaian khusus sebelum umum mempunyai tujuan teladan yang harus dilaksanakan terlebih dahulu ke atas orangorang yang terpilih dan khusus sebelum dapat dilaksanakan oleh orang awam dan dicontohi oleh mereka.

\section{Hadis Fatimah R.A}

Hadis Fatimah R.A ini terdapat dalam Sahih Bukhari di tiga tempat iaitu dalam kitab Fardu al-Khumus: 3113, kitab al-Nafaqat: 5361, dan kitab al-Da'awat: 6318, namun semuanya diriwayatkan oleh Saidina Ali RA yang dikhabarkan kepada Ibn Abi Laila kepada al-Hakam dan kemudiannya kepada Syu'bah.

Terjemahan hadis:

Ali R.A meriwayatkan bahawa Fatimah A.S telah datang mengadu kepada Rasulullah S.A.W tentang tangannya yang kasar dan telah sampai kepadanya perkhabaran adanya hamba sahaya diperoleh oleh kaum Muslimin) namun beliau (Fatimah) tidak berjaya menemuinya, lalu disebutnya perkara itu kepada Aisyah RA. Aisyah RA kemudiannya memberitahu kepada Nabi S.A.W. Ali R.A meriwayatkan: Lalu Nabi S.A.W datang ke rumah kami sedang kami telah berada di tempat tidur. Kami ingin bangun tetapi sabda Nabi S.A.W: “Tetaplah kamu ditempat kamu!"Baginda datang dan duduk diantara kami hingga aku terasa kaki baginda yang sejuk di atas perutku lalu baginda bersabda: "Tidakkah kamu ingin kutunjukkan kepadamu sesuatu yang lebih baik daripada apa yang engkau minta kepadaku. Apabila engkau hendak tidur, atau baring dipembaringan, maka bacalah SUBHANALLAH tiga puluh tiga kali, dan ALHAMDULILLAH tiga puluh tiga kali, serta ALLAHU AKBAR tiga puluh empat kali, maka itu lebih baik bagimu daripada seorang pembantu."

Terdapat dua interteks daripada riwayat ini iaitu kata-kata Rasulullah S.A.W:

1) Sabda Nabi S.A.W: عَلَى مَكَانِكُمَا " bermaksud:: "Tetaplah kamu ditempat kamu!"

2) Sabda Nabi S.A.W:

3)

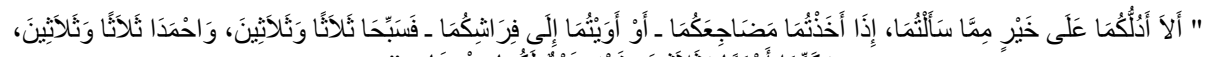

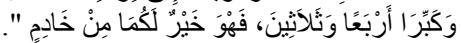


Bermaksud:

Tidakkah kamu ingin kutunjukkan kepadamu sesuatu yang lebih baik daripada apa yang engkau minta kepadaku. Apabila engkau hendak tidur, atau baring dipembaringan, maka bacalah SUBHANALLAH tiga puluh tiga kali, dan ALHAMDULILLAH tiga puluh tiga kali, serta ALLAHU AKBAR tiga puluh empat kali, maka itu lebih baik bagimu daripada seorang pembantu.

Dalam Sahih Bukhari hadis ini yang diletakkan di bawah kitab Fardu al-Khumus menyatakan ia dalil bahawa seperlima daripada rampasan perang ialah untuk kegunaan Nabi dan orang-orang miskin dan Nabi Muhammad S.A.W telah melebihkan keperluan ahli Suffah serta perempuan-perempuan janda yang lebih memerlukan daripada Fatimah R.A, anakanda baginda sendiri yang mengadu terpaksa bekerja berat dan memerlukan hamba pembantu, lalu baginda menyerahkan urusan anakanda baginda kepada Allah S.W.T yang akan mencukupkan keperluannya. Sementara itu dalam kitab al-Nafaqat pula diletakkan tajuk kerja wanita di rumah suaminya. Selain dari itu Imam Bukhari meletakkan pula tajuk menyebut tasbih dan tahmid ketika mahu tidur di dalam kitab al-Da'awat.

Kedua-dua interteks yang ditegaskan secara ketara oleh perawinya Saiyina Ali bin Abi Talib R.A merujuk kepada sabda Nabi S.A.W yang sebenarnya menterjemahkan perintah al-Quran bahawa manusia boleh memilih untuk berusaha bersungguh-sungguh demi kehidupan dunia dan akhirat, nescaya Allah akan berikan bantuan, namun orang yang memilih akhirat tentunya akan mendapat kelebihan di sisi Allah yang terdapat dalam surah al-Isra' 18-21:

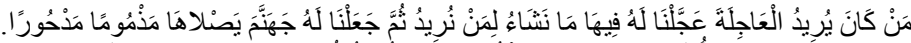

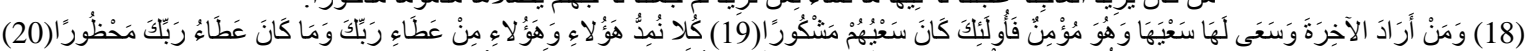

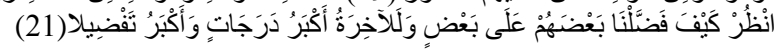

Ertinya:

Barangsiapa menghendaki kehidupan sekarang (duniawi), Maka kami segerakan baginya di dunia itu apa yang kami kehendaki bagi orang yang kami kehendaki dan kami tentukan baginya neraka jahannam; ia akan memasukinya dalam keadaan tercela dan terusir. Dan barangsiapa yang menghendaki kehidupan akhirat dan berusaha ke arah itu dengan sungguh-sungguh sedang ia adalah mukmin, Maka mereka itu adalah orang-orang yang usahanya dibalasi dengan baik." Kepada masing-masing golongan--baik golongan ini maupun golongan itu--Kami berikan bantuan dari kemurahan Tuhanmu. Dan kemurahan Tuhanmu tidak dapat dihalangi.Perhatikanlah bagaimana Kami lebihkan sebagian dari mereka atas sebagian (yang lain). Dan pasti kehidupan akhirat lebih tinggi tingkatnya dan lebih besar keutamaannya.

Oleh itu interteks daripada sabda Nabi Muhammad S.A.W mengandungi asas untuk diaplikasikan kepada keluarga baginda sendiri dahulu dan wajar diikuti oleh umat Islam amnya untuk kembali kepada Allah S.W.T di waktu senang dan susah.

\section{Hadis Ummu Ismail}

Hadis 3364 dari kitab Ahadith al-Anbiya (Cerita para Nabi) di dalam Sahih Bukhari ini dari riwayat Ibn Abbas merupakan hadis yang panjang bermula dengan:

$$
\begin{aligned}
& \text { عن ابن عباس رضي الله عنهما قال: أول ما اتخذ النساء المنطق من قبل أم إسماعيل، اتخذت منطقا لتعفي أثرها على سارة.... و وها يقو لان: } \\
& \text { ر ربنا تقبل منا إنك أنت السميع العليج). (بخاري: } 3364
\end{aligned}
$$

Terjemahan hadis:

Dari Ibnu Abbas RA. katanya: Mula - mula perempuan yang mengambil (memakai) ikat pinggang, ialah ibu Nabi Ismail, diambilnya ikat pinggang supaya hilang jejaknya oleh Sarah...

Kisah Ummu Ismail yang disebut di dalam riwayat ini berakhir dengan kematian Ummu Ismail, namun Ibn Abbas meneruskan lagi riwayatnya dengan kisah Nabi Ismail A.S bersama isteri dan ayahanda baginda Nabi Ibrahim A.S sehinggalah terbinanya Ka'bah dan kedua-duanya berdoa agar amalan mereka diterima oleh Allah SWT.

Kajian intertekstual dalam teks hadis:

Di dalam hadis riwayat Ibn Abbas RA ini terdapat enam interteks yang jelas dari sumber al-Quran dan kata-kata Rasulullah SAW:

i) Daripada al-Quran:

$$
\begin{aligned}
& \text { فانطلق إبر اهيم حتى إذا كان عند الثنية حيث لا برونه استقبل بوجهه البيت ثم دعا بهؤ لاء الكلمات ورفع يديه، فقال: }
\end{aligned}
$$

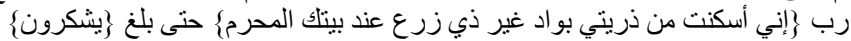

Ketika ia berada di Saniah, di tempat yang kira-kira tidak kelihatan oleh ibu Ismail, Ibrahim AS menghadap ke arah Bait, kemudian ia berdo'a dengan beberapa kalimat, sambil mengangkat kedua tangannya. Do'anya: "Wahai Tuhan kami! Sesungguhnya aku menempatkan sebahagian dari turunanku di lembah yang tiada mempunyai tanam-tanaman ,di dekat Rumah suci Engkau. Wahai Tuhan kami! Supaya mereka tetap mengerjakan sembahyang. Sebab itu, jadikanlah hati manusia tertarik kepada mereka,dan berilah mereka buah-buahan,menjadi rezeki mereka mudah-mudahan mereka berterima kasih!"

Di dalam hadis ini membezakan antara kata perawi dan sumber al-Quran dengan penanda. Ayat yang disebut terkandung di dalam surah Ibrahim, ayat 37.

Manakala interteks daripada Nabi Muhammad SAW dibezakan dari riwayat perawi melalui kata "sabda Nabi S.A.W" sebagaimana nombor ii, iii, iv, dan v di bawah:

ii) Daripada sabda Nabi Muhammad S.A.W:

$$
\text { فال النبي صلى اله عليه وسلم: 》فذلك سعي الناس بينهما《) }
$$

Rasulullah SAW bersabda: Kerana itulah orang haji mengerjakan Sa'i di antara Safa dan Marwah.

iii) Daripada sabda Nabi Muhammad S.A.W:

$$
\text { قال النبي صلى الله عليه وسلم: (ابرحم الله أم إسماعيل لو تركت زمزم -أو فال: لو لم تغرف من الماءـ لكانت زمزم عينا معيناه، }
$$

$$
\text { قال: فشربت وأرضعت ولدزما، }
$$


Nabi S.A.W. bersabda: Mudah-mudahan Tuhan mengasihi ibu Ismail! Jika dibiarkannya ZamZam, atau tidak disauknya air itu, sesungguhnya akan menjadi air mata air yang mengalir." Ibu Ismail lalu minum dan menyusukan anaknya.

iv) Daripada sabda Nabi Muhammad S.A.W:

$$
\begin{aligned}
& \text { قال: و أم إسماعيل عند الماء، فقالو ا: أتأذنين لنا أن ننزل عندك؟ فقالت: نعم، ولكن لا حق لكم في الماء، قالو ا: نعم. }
\end{aligned}
$$

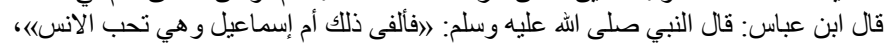
menerimanya dengan baik, kerana dia ingin ada orang lain bersama dia.

v) Daripada sabda Nabi Muhammad S.A.W:

$$
\text { قال النبي صلى الله عليه وسلم: 》اولم يكن لهم يومئذ حب، ولو كان لهم دعا لهم فيلها《. }
$$

Nabi S.A.W. bersabda: Ketika itu belum ada di situ tanaman yang berbiji. Sekiranya mereka mempunyai, niscaya Nabi Ibrahim mendoakan keberkatannya.

\section{vi) Daripada Firman Allah SWT}

$$
\text { و هما يقو لان: }\} \text { ربنا تقبل منا إنك أنت السميع العليمجر. }
$$

Sambil kedua-dua mengucapkan: Wahai Tuhan kami! Terimalah kerja kami. Sesungguhnya Engkau mendengar lagi mengetahui."

Penegasan ketara sandaran perawi kepada al-Quran diberikan penanda \{ \} untuk menjarakkannya dari kata-kata perawi dan mengisyaratkan kemasukan interteks daripada sumber lain sekalipun tidak dinyatakan ianya daripada al-Quran, nama surah dan ayatnya kerana perawi menjangkakan ianya adalah maklum dikalangan orang yang menerima hadis ini.

Kemasukan interteks daripada kedua-dua sumber al-Quran dan sabda Nabi S.A.W di dalam riwayat Ibn Abbas R.A sebagai penegasan terhadap prinsip Nabi Ibrahim A.S dan keluarga baginda dalam menjalani tanggungjawab dan tugas sebagai seorang Rasul di dalam kehidupan mereka yang perlu dicontohi oleh umat Islam.

\subsection{PERBINCANGAN}

Periwayatan hadis bertujuan untuk mengumpulkan ajaran Nabi Muhammad S.A.W. Oleh itu para perawi yang terdiri daripada para sahabat baginda dan keluarga baginda terutamanya Ummahatul Mu'minin cuba untuk memberikan gambaran sebenar kehidupan Rasulullah SAW supaya dapat dihayati oleh umat penerus generasi. Oleh itu kemasukan interteks daripada sumber utama iaitu al-Quran dan sabda Nabi SAW perlu dijarakkan daripada kata-kata perawi sebagai amanah penyampaian. Oleh kerana itu, kitab Sahih Bukhari menunjukkan penegasan ketara ini melalui kata "Firman Allah SWT" untuk ayat-ayat al-Quran atau ditandakan dengan penanda \{ \}, sementara katakata yang dihafaz daripada Rasullah SAW diasingkan dengan "sabda Nabi S.A.W."

Di dalam hadis takhyir, interteks al-Quran terkandung di dalam hadis Nabi kerana Nabi SAW diperintahkan memberi pilihan kepada para isteri baginda sama ada mahukan kesenangan hidup di dunia ataupun kehidupan yang dipilih oleh Nabi SAW. Ayat ini diturunkan tidak lama selepas kaum Muslimin pulang dari Perang Ahzab dengan memperoleh kemenangan yang gemilang dan berjaya memperoleh harta rampasan perang yang banyak yang menggembirakan kaum muslimin dan kaum wanita.

Oleh itu tatkala Nabi SAW mengucapkan perkara ini kepada isteri baginda ianya suatu yang berat kerana manusia sukakan kesenangan dan kemewahan. Memilih jalan kehidupan yang susah sepanjang hayat bersama baginda melibatkan masa depan yang perlu dipertimbangkan sebaiknya. Baginda tidak mahu isteri baginda, Aisyah R.A membuat keputusan ini sendirian lalu baginda meminta Aisyah R.A berbincang dengan keluarga sebelum membuat keputusan. Ucapan ini disampaikan dengan hati yang amat berat kerana kasihnya baginda terhadap isteri baginda terutamanya Aisyah R.A dan bimbang beliau akan memilih kesenangan sementara di dunia ini. Namun jawapan Aisyah RA yang tanpa ragu memilih Rasulullah S.A.W dan perjuangan baginda menunjukkan kejelasan akidah beliau dan sanggup berkorban apa sahaja demi keimanan tersebut. Beliau yakin dengan keputusan beliau tanpa perlu membincangkan hal ini dengan kedua orang tuanya terlebih dahulu kerana beliau rela dan bersedia menghadapi kehidupan mendatang yang penuh ranjau bersama Rasulullah S.A.W dan cara hidup pilihan baginda sebagai utusan Allah S.W.T. Inilah jalan yang dipilihnya sendiri menunjukkan daya tahan beliau demi sayangnya beliau kepada Allah S.W.T dan Rasul S.A.W melebihi dari apa yang diingini daripada kesenangan hidup material. Keputusan Aisyah R.A ini kemudiannya juga dituruti oleh semua para isteri baginda.

Daya tahan beliau ini jelas dalam satu lagi hadis yang diriwayatkan oleh anak saudara Aisyah R.A tentang kehidupan yang ibu saudaranya lalui melalui pilihannnya ini iaitu hadis yang diriwayatkan daripada 'Urwah, daripada Sayidatina Aisyah R.A menceritakan kepada Urwah: Wahai anak saudaraku, kami melihat bulan purnama,kemudian bulan purnama iaitu selama tiga kali purnama dalam dua bulan; Tidak dinyalakan api dirumah-rumah Rasulullah SAW (yakni dapur dirumah-rumah isteri Nabi tidak berasap).Lalu aku (yakni Urwah) bertanya, Wahai ibu saudaraku! Apakah makanan yang memberi kehidupan kepada kamu semua? Aisyah R.A menjawab, Al-Aswadain, (iaitu) Tamar dan Air, melainkan Rasulullah S.A.W mempunyai beberapa orang jiran daripada orang ansar yang mempunyai unta-unta yang dibenarkan untuk diambil susunya. Merekalah yang selalu menghadiahkan susu kepada Rasulullah S.A.W, maka dapatlah kami minum susu. (Riwayat al-Bukhari, kitab al-Hibah: no. 2567)

Di dalam sebuah hadis yang lain daripada Aisyah RA menceritakan : Nabi SAW wafat pada ketika kami semua kenyang dengan memakan tamar dan air. (Riwayat al-Bukhari, Kitab al-Ath'imah: no. 5383)

Nabi dan keluarga baginda termasuk isteri-isteri baginda dapat bertahan selama berbulan-bulan hanya dengan kurma dan air dan sesekali jiran tetangga beliau menghadiahkan susu kepada keluarga baginda. Bukan sahaja mereka hanya makan setakat memenuhi keperluan asasi paling minima bahkan mereka juga menginap di rumah yang hanya cukup untuk pembaringan sebagaimana yang diriwayatkan oleh Aisyah R.A:

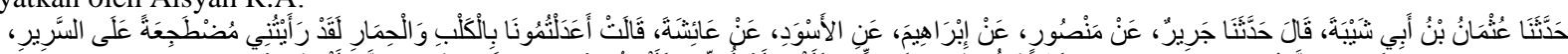

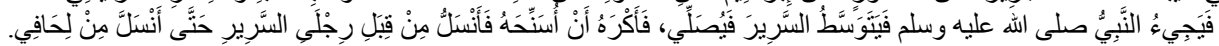

(Kitab Sahih Bukhari, Kitab al-Solah, no. 519) 
Adakah kamu menyamakan kami (kaum wanita) dengan anjing dan keldai (yang membatalkan solat)? Aku selalu tidur di atas katil, lalu datang Nabi SAW dan solat menghadap tengah katil. Aku tidak suka menjadi penghadang solat baginda, lalu aku menarik kakiku perlahan-lahan sehingga aku keluar daripada gebarku.

Hadis ini menunjukkan kediaman Aisyah R.A hanya bilik yang sempit. Ruangan solat hanya di hadapan katil isteri tidak menghalang baginda S.A.W sekalipun solat di hadapan isteri yang sedang tidur.

Jalan kehidupan susah yang dipilih ini bukan disebabkan baginda miskin tidak punya harta dan wang namun segala apa yang dimiliki digunakan untuk jalan dakwah baginda sehingga beliau dan keluarga rela hanya dibekalkan dengan bekalan makanan yang paling minima untuk meneruskan kehidupan mengabdikan diri hanya kepada Allah S.W.T. Ini kerana kehidupan yang mewah dan hidup yang dilimpahi dengan kesenangan hanya akan membawa manusia jauh dari Allah dan rahmatNya. Inilah jalan kehidupan yang dipilih oleh isteri-isteri Nabi untuk mencapai kedudukan yang tinggi di sisi Allah S.W.T. Kehidupan yang susah ini menjadikan mereka kental menghadapi sebarang ujian walaupun setelah kewafatan Nabi S.A.W.

Amalan interteks di dalam riwayat ini adalah sumber kekuatan praktis Islami yang ditunjukkan oleh Rasulullah SAW dan keluarga baginda. Interteks daripada sumber al-Quran dan sabda Nabi menunjukkan keselarian antara ajaran yang sampaikan oleh Nabi Muhammad S.A.W dan amalan kehidupan baginda sendiri untuk dicontohi.

Interteks di dalam hadis Fatimah RA menunjukkan keprihatinan baginda terhadap anak perempuan baginda walaupun telah bersuami. Sekalipun baginda seorang ayah dan pemimpin besar umat Islam dan lebih mulia seorang utusan Allah, baginda tidak membenarkan anak menantu baginda bangun bahkan datang duduk bersama mereka dan menerangkan kepada mereka apa yang terbaik untuk mereka. Walaupun mengetahui kemiskinan hidup Fatimah R.A, baginda tidak dapat menunaikan permintaan beliau kerana ada yang lebih layak daripada beliau menerima hamba sahaya tersebut. Namun begitu beliau tidak mensesiakan permohonan itu dengan memberi motivasi jiwa yang boleh menjadi bekalan mereka bahkan dapat mengatasi ketidakcukupan tersebut. Rasulullah SAW mahukan anak menantu baginda untuk mendapat kemuliaan di sisi Allah S.W.T dan baginda tahu kesukaran hidup anakanda baginda menjadikan mereka lebih dekat dengan Allah S.W.T dan hanya menaruh pergantungan kepada Allah yang Berkuasa dengan memperbanyakkan zikir terhadapNya. Fatimah R.A sebagai anak seorang utusan Allah serta sebagai isteri seorang panglima tentera yang sentiasa ditinggalkan bersendirian menguruskan segala urusan rumahtangga daripada mengisar tepung untuk dijadikan roti, mengangkut air, mengasuh dan memberi didikan yang sempurna kepada anak-anak yang masih kecil, menjaga kebersihan rumah, memberi makan ternakan dan lain-lain tanpa rehat, menuntut daya tahan dan kesabaran yang tinggi seorang wanita dalam menguruskan rumahtangga, unit terkecil kehidupan bermasyarakat. Beliau tidak dilimpahkan dengan kemewahan dan kesenangan hidup walaupun di saat itu umat Islam telah mula mendapat kejayaan demi kejayaan dalam peperangan dengan mendapat harta dan rampasan yang banyak. Itulah tarbiah Rasulullah S.A.W kepada anakanda baginda demi mendapat keredhaan Allah S.W.T. Begitulah juga wanita-wanita lain yang ingin memperoleh kemuliaan ini harus mempunyai daya tahan yang kuat dalam menghadapi segala rencah kehidupan.

Oleh itu interteks di sini memberi penegasan kepada apa yang ingin disampaikan oleh Rasulullah S.A.W bahawa dengan mengingati Allah S.W.T itu akan mendapat kekuatan mental dan fizikal untuk meneruskan kehidupan di samping menjadi bekalan akhirat. Interteks ini memberi motivasi kesabaran kepada setiap yang menghadapi kesusahan dalam kehidupan supaya tidak berputus asa dan sentiasa bergantung harap kepada Allah S.W.T. Riwayat ini membuktikan aplikasi dalam kehidupan Nabi dan para keluarga baginda.

Di dalam hadis Ummu Ismail, kemasukan teks al-Quran di dalam riwayat ini menunjukkan kesinambungan dan penjelasan kepada sumber ayat yang diturunkan dalam Surah Ibrahim antara ayat 37 sebagaimana yang dibawa di atas.

Klausa 'di lembah yang tidak mempunyai tanam-tanaman di dekat rumah Engkau (Baitullah) yang dihormati.' Menunjukkan ujian yang perit kepada seorang wanita dalam keadaan beliau mempunyai anak kecil dan ditinggalkan pula di lembah gersang , apakah tindakan beliau. Ummu Ismail tidak sekali-kali berputus asa bahkan berusaha bersungguh-sungguh mengatasi permasalahannya dengan segala kudrat yang dimilikinya tanpa mengeluh bahkan mencari dan mencari sehingga mendapat pertolongan Ilahi.

Oleh itu, hadirnya interteks daripada al-Quran ini adalah penting disebut kerana ia merupakan sumber kekuatan kepada Hajar (Ummu Ismail) saat diuji ditinggalkan bersama anaknya tanpa apa pun melainkan kepercayaannya kepada Allah S.W.T. Daya tahan Ummu Ismail ini adalah berkat doa Nabi Ibrahim A.S tanpa pengetahuannya supaya Allah S.W.T memelihara mereka untuk beribadat kepadaNya walau dalam keadaan apa sekalipun. Ibn Kathir dalam tafsirnya menyebut bahawa doa yang dirakamkan dalam ayat 35-41dalam surah Ibrahim, diucapkan semula oleh Nabi Ibrahim setelah terbinanya Kaabah dan Mekah semakin berkembang dan makmur berkat dari permintaan yang telah dimakbulkan.

Seterusnya Ibn Abbas R.A meriwayatkan bahawa Rasulullah S.A.W. bersabda: "Kerana itulah orang haji mengerjakan Sa'i di antara Safa dan Marwah.'Interteks daripada Rasulullah SAW ini membuktikan bahawa Nabi S.A.W telah mengaitkan perbuatan Ummu Ismail dengan pekerjaan ibadat sa'i yang diwajibkan semasa melakukan rukun haji, menunjukkan penghargaan Islam terhadap wanita yang begitu sabar saat beliau diuji beliau tidak berputus asa dan perbuatan ini menjadi lambang usaha gigih yang perlu dilakukan oleh umat Islam untuk melahirkan generasi yang hebat mengabdikan diri kepada Allah serta memerlukan daya tahan individu Muslim.

Perbuatan ini menjadi syiar Islam dalam menunjukkan ketaatan kepada Allah S.W.T dengan usaha yang bersungguh-sungguh untuk mencapai keredhaan Ilahi.

Interteks yang berikutnya daripada Rasulullah S.A.W sekali lagi memuji Ummu Ismail dengan sabda baginda : "Mudah- mudahan Tuhan mengasihi ibu Ismail! Jika dibiarkannya ZamZam, atau tidak disauknya air itu, sesungguhnya akan menjadi air mata air yang mengalir.'

Ianya penghargaan terhadap kebijaksanaan Ummu Ismail yang tidak melepaskan suatu yang berharga dihadapannya bahkan berbuat sesuatu untuk mengekalkan sumber air yang sukar diperolehi ditanah gersang itu. Tindakan beliau yang bijak semasa berlakunya peristiwa itu menyebabkan ramai yang memperoleh sumber air ini sehingga zaman berzaman dengan berkat Ilahi.

Interteks yang keempat daripada sabda Nabi SAW: "Ibu Ismail menerimanya dengan baik,kerana dia ingin ada orang lain bersama dia". Pernyataan ini sekali lagi menunjukkan survival Ummu Ismail dan anaknya yang mempertahankan hak mereka atas sumber air yang diperoleh namun tidak sekali-kali tamak kerana sanggup berkongsi dengan orang yang meminta air tersebut. Survival yang ditunjukkan oleh Ummu Ismail ini menunjukkan daya tahan seorang ibu yang berfikir untuk memenuhi keperluan anaknya dengan mengambil dua pendekatan iaitu berbaik dengan kaum yang mendatang untuk mewujudkan masyarakat yang boleh saling bantu membantu dan dalam masa yang sama tidak melepaskan kekuasaan atas sumber tersebut sehingga beliau dan anaknya dihormati serta diakui oleh kaum yang mendatang sebagai pemilik dan penguasa air yang dinikmati bersama itu. 
Interteks yang kelima masih meneruskan kesinambungan survival keluarga Nabi Ibrahim A.S di bumi gersang ini dimana mereka berkecukupan dengan hanya bekalan air zamzam dan buah kurma natijah keberkatan doa Nabi Ibrahim A.S atas kedua makanan asasi penduduk Mekah ini. Penegasan ketara kata nabi s.a.w. "Ketika itu belum ada di situ tanaman yang berbiji. Sekiranya mereka mempunyai, niscaya Nabi Ibrahim A.S mendoakan keberkatannya." Ini menunjukkan keluarga Nabi Ibrahim A.S hidup dalam keadaan bersyukur dan ini punca keberkatan hidup mereka yang perlu dicontohi oleh umat manusia.

Riwayat Ibn Abbas R.A menutup dengan interteks daripada al-Quran setelah sempurna tugas pembinaan Kaabah di bumi gersang itu oleh Ibrahim A.S dan anaknya Ismail A.S dengan doa keduanya agar usaha mereka diterima oleh Allah S.W.T. Pembinaan ini titik tolak kepada pembangunan Mekah yang pada asalnya didiami oleh seorang wanita yang berjiwa teguh untuk membesarkan anaknya dengan penuh keyakinan bahawa Allah S.W.T yang Maha Mendengar lagi Maha Mengetahui tidak akan membiarkan mereka tanpa sebarang pertolongan.

Oleh itu riwayat ini tidak hanya sebuah cerita atau sejarah dahulukala bahkan di dalamnya terkandung pengajaran yang besar yang perlu dikaji dari pelbagai sudut antaranya melalui kehadiran interteks daripada Nabi S.A.W.

\subsection{KESIMPULAN}

Melalui analisis hadis takhyir, hadis Fatimah R.A dan hadis Ummu Ismail tercermin keunggulan wanita terdahulu yang berjaya membina generasi yang kuat dan maju. Pemerhatian ke atas teks yang diriwayatkan oleh mereka sendiri atau para sahabat lain menunjukkan kemasukan interteks di dalamnya mempunyai tujuan penegasan ke atas sesuatu prinsip dan asas yang dipegang oleh mereka iaitu keimanan dan keyakinan terhadap Allah S.W.T dan panduan Rasulullah S.A.W. Asas inilah praktis Islami yang menjadi dorongan tindakan mereka pada ketika itu. Prinsip para wanita terdahulu yang berasaskan sumber al-Quran dan sabda Nabi S.A.W ini sepatutnya memberi impak kepada generasi sekarang dan wajar dicontohi serta diaplikasi oleh para wanita sekarang supaya turut mempunyai daya tahan yang kuat dalam menghadapi pelbagai fitnah dan cabaran kehidupan melalui penghayatan riwayat-riwayat hadis Nabi S.A.W. Melalui analisis wacana hadis seperti ini terbukti hubungkait amalan wacana dan proses sosial yang berlaku ketika itu yang perlu diteliti dan dijiwai oleh masyarakat Islam seluruhnya untuk mencapai natijah yang sama iaitu menjadi (khaira ummatin) sebaik-baik ummah.

\section{Rujukan}

Abdul Mun'im al-Hanafi. (1423H/ 2003M). Mawsu'ah Ummul Mu'minin Aisyah binti Abi Bakr. Cetakan pertama. Kaherah: Maktabah al-Mad Buli. Abu Audah, Audah Khalil. (1991). Bina' al-Jumlah fi al-Hadith al-Nabawi al-Sharif fi al-Sahihayn. Cetakan 1. Amman: Dar al-Basyir.

Abu Syuqqah, Abdul Halim Muhammad.(2009). Jati Diri Wanita Menurut al-Quran dan Hadis. Alihbahasa Zulkifliee Yazid. Kuala Lumpur: Pustaka Al-Shafa.

Ahmadi, Khaulah \& Sahrawi, Nazihah. (2013). Asalib Hiwar al-Rasul ma'a Zaujatihi ka Namuzaj li Tahqiq Fa'aliayatu al-Hiwar wa al-Tawafuq al-Zawaji fi alUsrah al-Jaza 'iriyyah. Algiers: Al-Multaqa al-Watani 2.

Al- Sha'rawi, Muhammad Mutawalli. (2001). Zawjatun Nabi wa Aalul Bayt. Kaherah: alMaktabah al-Tawfiqiyyah.

Al-'Aini, Badr al-Din. (1972). 'Umdah al-Qari Sharh Sahih al-Bukhari. Juz 1. Cetakan 1. Mesir: Maktabah Albani al-Halabi.

Al-Budur, Hanan. (2010). Al-I'dad al-Tarbawi lil Usrah Muslimah fi 'Asr al- "ulimah. Tesis PhD. Yarmouk: Kuliyyah Shari'ah, Yarmouk University.

Al-Bukhari, Muhammad. (1997). Shahih Bukhari. Cetakan ke 5. Terjemahan H. Zainuddin Hamidy, H. Fachruddin Hs, H. Nashruddin Thaha, et al. Klang: Klang Book Centre.

Al-Jundiy, Darwish. (t.th) Ilm al-Ma'ani. Kaherah: Dar Nahdah Misr.

Al-Jurjani, Abd al-Qahir. (2001). Dala'il al-I'jaz fi Ilm al-Ma'ani. Edit: Sa'ad Karim al-Faqiy. Al-Mansurah: Dar al-Yaqin.

Al-Jurjani, Abd al-Qahir. (t.th.). Asrar al-Balaghah fi Ilm al-Bayan. Edit: Muhammad Rashid Rida. Dar al-Matbu'at al-Arabiyah.

Al-Kandari, Latifah Hussein dan Malik, Badr Muhammad. (2005). Tarbiyatul Mar'ah min Manzur al-Sheikh Muhammad al-Ghazali. Cetakan pertama. Jeddah: Maktabah Bustan al-Ma'rifah.

Al-Majid,Kalthum Umar Ubayd. (2010). Al-Jawanib al-Tarbawiyah min Sirah Ummahat al-Mu'minin radhiyallu ta'ala anhunna. Tesis M.A Irbid: Universiti Yarmouk.

Al-Moumani, Insaf. (2013). Hadyu al-Nabawiy SAW Fi al-Ta'amul Ma'a Zaujatihi (Aishah Ummul Mu'minin RA Namuzajan). Saudi Arabia: King Abdul Aziz Universiti.

Al-Qanuji al-Bukhary, As-Saiyid Muhammad Siddiq Khan. (1981). Husnul Uswah Bima Thabata min Allah wa Rasulihi fi al-Niswah. Disunting oleh Dr. Mustafa Sa'id al-Khan dan Mustawi. Cetakan pertama. Beirut: Muassasah al-Risalah.

Al-Qanuji al-Bukhary, As-Saiyid Muhammad Siddiq Khan. (2001). Al-Quran dan As-Sunnah Bicara Wanita. Alihbahasa Kathur Suhardi. Jakarta Timur: Darul Falah. Al-Quran al-Karim

Al-Salih, Subhi. (2000). Mabahith fi Ulum al-Hadith wa Mustolahihi: 'Ardh wa Dirasah. Cetakan 24. Beirut: Dar al-Ilm li al-Malayin.

Al-Sheikh, Badwi Mahmud. (1995). Riyadh al-Salihat: Qutuf Tarbawiyah min Bustan al-Nubuwwah. Kaherah: Dar al-Salam.

Al-Tantawi, Ali. (1989). Ta'rif 'Aam bi Din al-Islam. Cetakan ke 13. Kaherah: Dar al-Wafa'

Al-Za'biy, Muhammad Muslih. (2008). Al-Hiwar al-Nabawiy ma'a al-Mar'ah fi bina'shaksiyyatuha. Jordan Journal of Islamic Studies, 5(3).

As-Siba'I, Mustafa. (1999). Al-Mar'ah bayna al-Fiqh wa al-Qanun. Cetakan ke 7. Damsyik: Dar al-Warraq.

Dawudi, Safwan. (1422 H). al-Hujurat al-Sharifah: Sirah wa Tarikhan. Cetakan ke2. Al- Madinah al-Munawwarah: Waqaf al-Barakah al-Khairi.

Fairclough, N. (1989). Language and Power. London, UK: Longman.

Fairclough, N. (1992). Discourse and Social Change. Cambridge, UK: Polity Press.

Fairclough, N. (1995). Critical Discourse Analysis: The Critical Study of Language. London, UK: Longman.

Fairclough, N. (2002). Analysing Discourse: Textual analysis for Social Research. London, UK: Routledge.

Fairclough, Norman. (2003). Analysing Discourse: Textual Analysis for Sosial Research. New York: Routledge.

Ibn Hajar al-Asqalani, Ahmad bin Ali. (1986). Fath al-Bari Sharh al-Bukhari. Dar al-Rayyan li al-Turath.

Ibn Hisham. (1992). Al-Sirah al-Nabawiyah.edit al Saqa et al. juz 1. Beirut: Dar al-Khair.

Ibrahim, Nasir Radhi Al-Zuhri. (2008). Balaghah al-Rasul fi Taqwim akhta' al-Nas wa Islah al-Mujtama': dirasah fi al-sahihayn. Kaherah: Dar al-Basa'ir.

Idris Aman. (2006). Bahasa dan Kepimpinan. Analisis Wacana Mahathir Mohamad. Bangi: Penerbit UKM.

Mohd Akil Muhammad Ali, Mazlan Ibrahim, Dwi Sukmanilla Sayska.(2011). Hadith “anti-wanita” berkenaan dengan Kehidupan Rumah Tangga: Kajian Kritik terhadap Feminis Liberal. Bil 9. Al-Bayan: Jurnal al-Qur'an dan al-Hadith, pp 135-166.

Mohd. Azidan Abdul Jabar. (2010). Analisis Wacana Arab. Kuala Lumpur: Dewan Bahasa \& Pustaka.

Munif Zariruddin Fikri bin Nordin. (2008). Bahasa Kepimpinan Rasulullah SA.W: Analisis wacana khutbah Ghazawat al-Rasul. UM: Tesis PhD.

Munif Zariruddin Fikri bin Nordin. (2012). Analisis Wacana Prinsip Kesantunan Berbahasa dalam al-Quran dan Hadis. Dlm Marlyna Maros, Mohammad Fadzeli Jaafar, Maslida Yusof (penytg) Prinsip dan Aplikasi Kesantunan Berbahasa. Kuala Lumpur: Dewan Bahasa dan Pustaka. 
Salim, Muhammad Ibrahim. (1990). Nisa' Hawla al-Rasul. Kaherah: Maktabah Ibn Sina

Sekumpulan penyelidik. (2013). Mawsu'ah A'isyah Ummul Mu'minin. Cetakan 1. Saudi Arabia: Muassasah al-Doror al-Sunniyah li al-nashr. www.dorar.net

Umar, Mukhtar Ibrahim. (2011). Al-Tariqah al-Nabawiyyah fi Halli Khilafat al-Zaujiyyah. Tesis M.A. Malaysia: Jami'ah al-Madaniyyah al-Maliziyyah.

\section{Appendiks}

Teks hadis takhyir

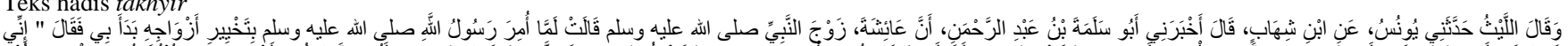

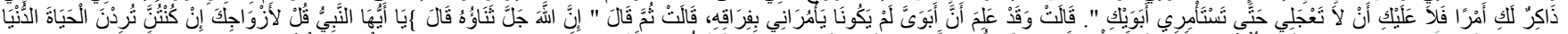

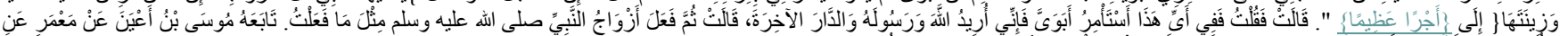

Teks hadis Fatimah

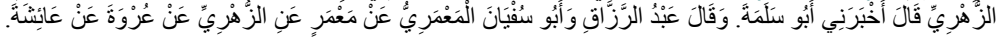

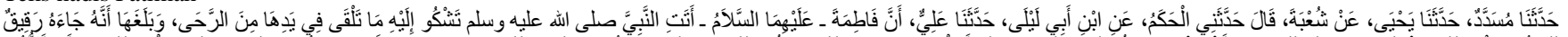

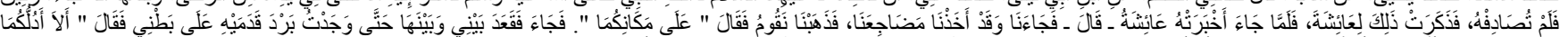

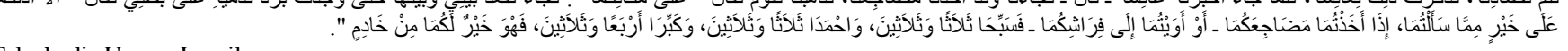

Teks hadis Ummu Ismail

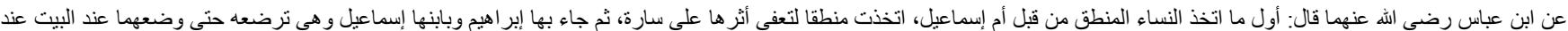

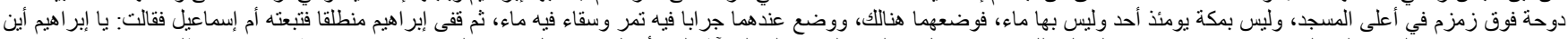

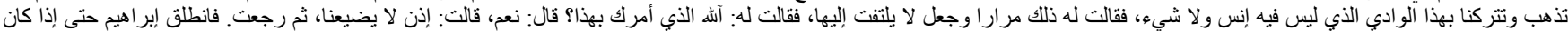

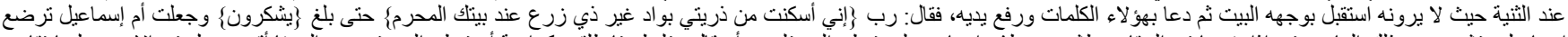

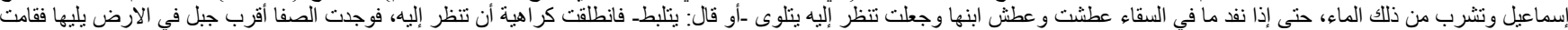

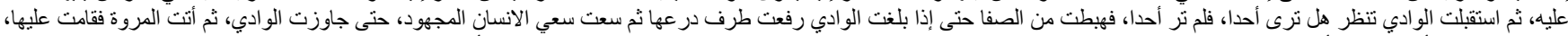

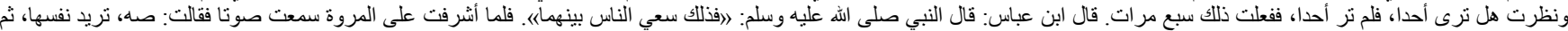

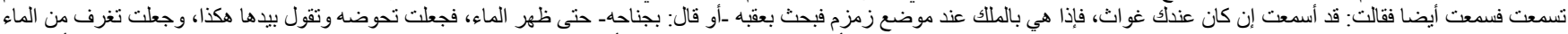

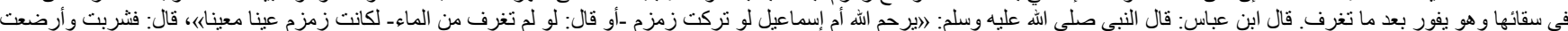

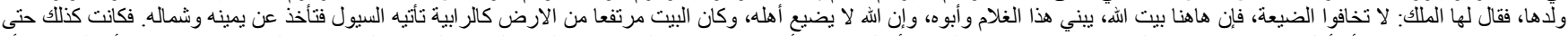

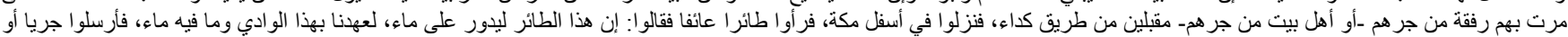

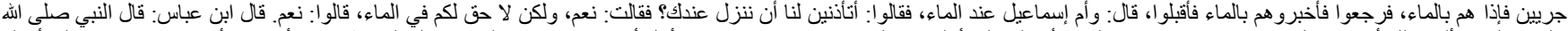

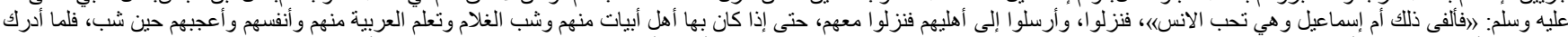

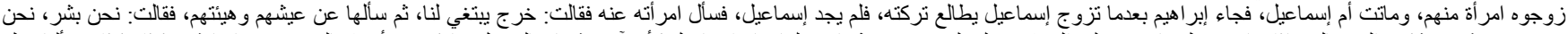

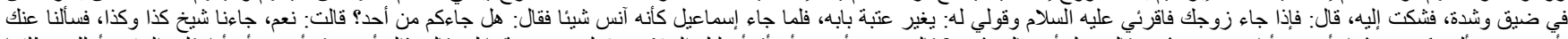

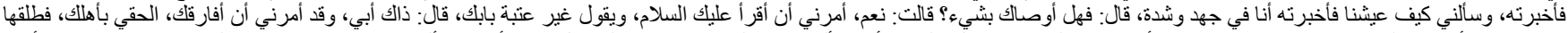

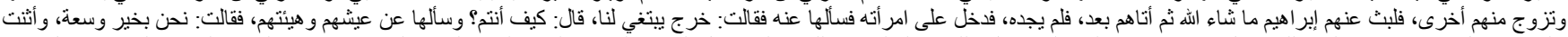

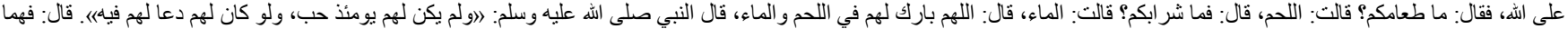

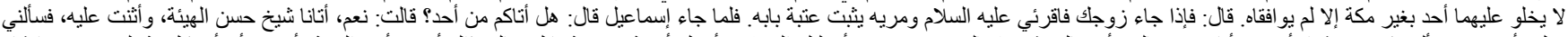

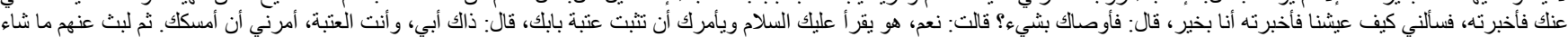

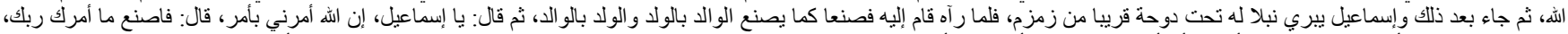

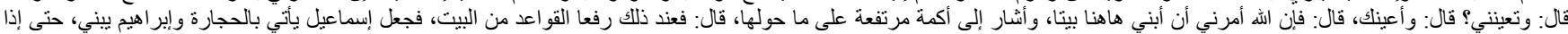

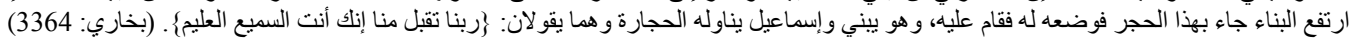

